\title{
Implementasi Model Pembelajaran Kooperatif Contextual Teaching and Learning untuk Meninggkatkan Hasil Belajar Matematika Pokok Bahasan Aritmatika Sosial bagi Siswa SMP Negeri 1 Pemenang
}

\author{
Uswatun Hasanah \\ SMPN 1 Pemenang, Kabupaten Lombok Utara - Provinsi NTB \\ *Corresponding Author. Email: uswatunhasanahtembobor@gmail.com
}

\begin{abstract}
The purpose of this research is to improve the mathematics learning outcomes of social arithmetic subjects for students through the application of the contextual teaching and learning (CTL) cooperative learning model. The research method used is classroom action research which is carried out in two cycles. The subjects of this study were students of class VII.2 of SMP Negeri 1 Pemenang, totaling 21 students. This research instrument uses observation sheets, documentation, and tests. While the data analysis technique used is quantitative descriptive analysis. The results of this study indicate that student learning outcomes have increased by an average of $9 \%$ obtained from the average evaluation of student learning outcomes from the first cycle is $76 \%$ then increased in the second cycle to $85 \%$. So it can be concluded that the application of the cooperative learning model can create participatory and multidirectional learning and can improve student learning outcomes. The results also show changes in the classroom atmosphere that tend to be democratic and changes in teacher attitudes to care more about the classroom atmosphere.
\end{abstract}

Abstrak: Tujuan dari penelitian ini adalah untuk meningkatkan hasil belajar matematika pokok bahasan bahasan aritmatika sosial bagi siswa melalui penerapan model pembelajaran kooperatif contextual teaching and learning (CTL). Metode penelitian yang digunakan adalah penelitian tindakan kelas yang dilakukan dalam dua siklus. Subjek penelitian ini adalah siswa kelas VII.2 SMP Negeri 1 Pemenang yang berjumlah 21 orang. Instrument penelitian ini menggunakan lembar observasi, dokumentasi, dan tes. Sedangkan teknik analisis data yang digunakan adalah analisis deskriptif kuantitatif. Hasil penelitian ini menunjukkan bahwa hasil belajar siswa mengalami peningkatan rata-rata $9 \%$ diperoleh dari rata-rata evaluasi hasil belajar siswa dari siklus I adalah $76 \%$ kemudian meningkat pada siklus II menjadi 85\%. Sehingga dapat disimpulkan bahwa penerapan model pembelajaran kooperatif dapat menciptakan pembelajaran yang partisipatif dan multiarah serta dapat meningkatkan hasil belajar siswa. Hasil penelitian juga menunjukkan perubahan suasana kelas yang cenderung demokratis dan perubahan sikap guru untuk lebih peduli terhadap suasana kelas.

\section{Article History}

Received: 09-11-2021

Revised: 14-12-2021

Accepted: 22-12-2021

Published: 07-01-2022

\section{Key Words:}

Cooperative, Contextual Teaching and Learning, Learning Outcomes, Social Arithmetic.

\section{Sejarah Artikel}

Diterima: 09-11-2021

Direvisi: 14-12-2021

Disetujui: 22-12-2021

Diterbitkan: 07-01-2022

\section{Kata Kunci:}

Kooperatif, Contextual Teaching and Learning, Hasil Belajar, Aritmatika Sosial.

How to Cite: Hasanah, U. (2022). Implementasi Model Pembelajaran Kooperatif Contextual Teaching and Learning untuk Meninggkatkan Hasil Belajar Matematika Pokok Bahasan Aritmatika Sosial bagi Siswa SMP Negeri 1 Pemenang. Jurnal Paedagogy, 9(1), 159-167. doi:https://doi.org/10.33394/jp.v9i1.4536

\section{Pendahuluan}

Pendidikan adalah upaya terus menerus dan tidak pernah berhenti yang harus dilaksanakan, baik itu oleh seorang individu maupun institusi. Walaupun disadari bahwa pendidikan merupakan proses yang panjang dengan modal dan pengorbanan yang besar disertai dengan kesabaran yang tinggi (Munif, 2013). Namun setiap individu maupun institusi selalu menjadikan pendidikan sebagai suatu yang sangat penting untuk dapat meningkatkan 
kualitas sumber daya manusia. Selain itu, pendidikan merupakan pondasi terpenting yang mendasari keberhasilan manusia dalam bidang-bidang kehidupan, khususnya keberhasilan peserta didik dalam belajar dengan ditunjukkan oleh kemampuan peserta didik dalam meraih hasil belajar yang optimal (Saufi \& Rizka, 2021; Suarni, et al., 2021).

Keberhasilan tersebut tidak terlepas dari peran guru yang memberikan pelayanan terbaik bagi peserta didik serta mampu mengemas metode pembelajaran yang dapat diterima sepenuhnya oleh siswa di sekolah. Keberhasilan pengajaran sangat ditentukan manakala pengajaran tersebut mampu mengubah perilaku dan pola pikir peserta didik dalam belajar. Perubahan tersebut dalam arti dapat menumbuhkembangkan potensi-potensi yang dimiliki peserta didik, sehingga peserta didik dapat memperoleh manfaatnya secara langsung dalam perkembangan pribadinya (Reostiyah, 2001). Tanggung jawab keberhasilan pengajaran tersebut berada di tangan guru. Artinya, guru harus berupaya semaksimal mungkin untuk mengatur proses pembelajaran sedemikian rupa, sehingga komponen-komponen yang diperlukan dalam pengajaran tersebut dapat berinteraksi antar sesama komponen (Zaini, 2008).

Dalam proses belajar mengajar menurut Sudjarwo (Suryani, 2018), paling tidak ada 6 (enam) kejadian penting yang perlu ada dan perlu diperhatikan, yaitu: (1) Ciptakan dan jaga perhatian siswa. (2) Tunjukkan keterkaitan pesan yang sedang diajarkan dengan pesan yang telah diterima sebelumnya. (3) Arahkan proses belajar mengajar dengan menggunakan bahan-bahan, visual, audio, verbal dan kombinasi dari berbagai bahan tersebut. (4) Ciptakan komunikasi 2 (dua) arah yang baik dan seimbang, sehingga umpan balik dari dan ke sasaran didik dapat dimanfaatkan untuk mempercepat tingkat kesamaan bahasa dan persepsi peserta didik. (5) Ciptakan dan pelihara kondisi untuk mengingat-ingat, menganalisa, menyimpulkan, menerapkan dan mengevaluasi pesan yang diterima siswa. (6) Selama dan setelah selesai belajar, sebaiknya dilakukan kegiatan evaluasi sesuai dengan tingkat formalitas masingmasing situasi belajar.

Untuk menciptakan terjadinya 6 (enam) kejadian penting tersebut di atas, antara lain diperlukan penggunaan model pembelajaran yang tepat, agar tercapainya harapan tersebut, seorang guru harus terampil dalam memilih model yang tepat dan sesuai dengan pokok bahasan yang dibahas (Nilawati, 2021).Untuk mengatasi kesulitan proses pembelajaran dalam pelajaran matematika, maka usaha yang akan ditempuh dalam upaya meningkatkan hasil belajar peserta didik adalah dengan penggunaan model pembelajaran yang tepat sehingga diharapkan akan terjadi Pembelajaran Aktif, Kreatif, Efektif dan Menyenangkan (PAKEM), khususnya pada mata pelajaran matematika (Heryekti, 2021).

Berdasarkan hasil nilai ulangan sebelumnya pada adalah siswa kelas VII.2 SMP Negeri 1 Pemenang, bahwa siswa masih kesulitan dalam menyelesaikan soal evaluasi yang bersifat analisis, siswa masih kesulitan menyelesaikan dan memecahkan masalah. Hal itu berarti indikator berpikir kritis yaitu mampu menganalisis, mampu mengenal dan memecahkan masalah yang dilakukan oleh siswa masih rendah. Hal lain yang bisa dilihat dari kurangnya keterampilan berpikir kritis siswa yaitu dalam menyelesaikan soal evaluasi, dimana hasil belajar yang diperoleh masih rendah, persentasi ketuntasannya hanya $71,4 \%$.

Pemilihan model dalam pembelajaran oleh guru bukan merupakan hal yang mudah, karena disetiap kelas itu dipenuhi oleh kemampuan akedemik peserta didik yang heterogen. Dalam proses belajar mengajar dengan menggunakan model yang tepat maka peserta didik akan mampu memahami pesan yang terkandung dalam pelajaran tersebut. Model pembelajaran kooperatif model CTL (Contextual Teaching And Learning) diharapkan mampu meningkatkan hasil belajar siswa di kelas (Burungge, 2020; Asmawati, 2018). Adapun tujuan 
penelitian ini adalah untuk meningkatkan hasil belajar matematika pokok bahasan bahasan aritmatika sosial bagi siswa melalui penerapan model pembelajaran kooperatif contextual teaching and learning (CTL) bagi siswa kelas VII.2 SMP Negeri 1 Pemenang.

\section{Metode Penelitian}

Metode penelitian ini menggunakan penelitian tindakan kelas yang dilaksanakan dalam dua siklus. Setiap siklus terdiri dari 3 pertemuan dengan alokasi waktu yang telah dijadwalkan. Dari masing-masing siklus dilaksanakan tahapan-tahapan yang meliputi tahap perencanaan, pelaksanaan tindakan, observasi dan evaluasi, dan refleksi. Subjek penelitian ini adalah siswa kelas VII.2 SMP Negeri 1 Pemenang yang berjumlah 21 orang. Data hasil belajar siswa dikumpulkan dengan memberikan tes kemampuan siswa. Sedangkan data aktivitas siswa dan kegiatan guru dalam proses belajar mengajar dikumpulkan dengan menggunakan lembar obervasi. Data tentang aktivitas belajar siswa dianalisis secara deskripsif kualitatif. Indikator tentang aktivitas belajar siswa yang diamati adalah sebanyak 5 indikator. Setiap indikator memiliki 3 deskriptor. Skor 1 diberikan jika deskriptor nampak dan skor 0 diberikan jika deskriptor tidak nampak.

Tabel 1. Pedoman Kriteria Untuk Menentukan Aktivitas Belajar

\begin{tabular}{|l|l|l|}
\hline \multicolumn{1}{|c|}{ Interval } & \multicolumn{1}{c|}{ Skor } & \multicolumn{1}{c|}{ Kategori } \\
\hline $\mathrm{MI}+1,5 \mathrm{SDI} \leq \mathrm{s} \leq \mathrm{MI}+3 \mathrm{SDI}$ & $11,25 \leq \mathrm{s} \leq 15,00$ & Sangat aktif \\
\hline $\mathrm{MI}+0,5 \mathrm{SDI} \leq \mathrm{s} \leq \mathrm{MI}+1,5 \mathrm{SDI}$ & $8,75 \leq \mathrm{s}<11,25$ & Aktif \\
\hline $\mathrm{MI}-0,5 \mathrm{SDI} \leq \mathrm{s}<\mathrm{MI}+0,5 \mathrm{SDI}$ & $6,25 \leq \mathrm{s}<8,75$ & Cukup aktif \\
\hline $\mathrm{MI}-1,5 \mathrm{SDI} \leq \mathrm{s}<\mathrm{MI}-0,5 \mathrm{SDI}$ & $3,75 \leq \mathrm{s} \leq 6,25$ & Kurang aktif \\
\hline $\mathrm{MI}-3 \mathrm{SDI} \leq \mathrm{s}<\mathrm{MI}-1,5 \mathrm{SDI}$ & $0,00 \leq \mathrm{s}<3,75$ & $\begin{array}{l}\text { Sangat Kurang } \\
\text { Aktif }\end{array}$ \\
\hline
\end{tabular}

Hasil tes belajar dianalisis secara deskriptif yaitu dengan menentukan nilai rata-rata hasil tes. Adapun indikator keberhasilan penelitian ini yakni; (1) aktivitas belajar siswa meningkat apabila terjadi peningkatan skor rata-rata dari skor sebelumnya dan minimal berkategori aktif; dan (2) hasil belajar siswa meningkat apabila terjadi peningkatan nilai rata-rata dari nilai rata-rata sebelumnya dengan ketuntasan belajar siswa minimal 85\%.

\section{Hasil Penelitian dan Pembahasan}

Pada penelitian ini, data tentang aktivitas belajar siswa dan kegiatan guru dalam proses belajar mengajar diperoleh dari lembar observasi sedangkan data tentang hasil belajar siswa diperoleh dari hasil tes. Data-data yang diperoleh dianalisis dengan menggunakan metode yang telah ditetapkan sebelumnya. Hasil penelitian pada tiap-tiap siklus adalah sebagai berikut:

\section{Deskripsi Siklus I}

Proses belajar mengajar siklus 1 berlangsung dalam 3 pertemuan. Pertemuan 1 berlangsung selama 2 x 40 menit dan pertemuan 2 berlangsung 3 x 40 menit. Sedangkan pertemuan 3 berlangsung selama 2 x 40 menit digunakan untuk diskusi dan evaluasi selama 60 menit. Adapun sub pokok bahasan yang dibahas pada siklus 1 adalah memahami keuntungan dan kerugian, bunga tunggal. Sedangkan pada siklus 2 pengertian bruto,netto dan tara dan memahami contoh tentang bruto, netto dan tara pada kehidupan sehari-hari.Sedangkan pertemuan 3 dilakukan diskusi dan kegiatan evaluasi. Kegiatan pada siklus 1 terdiri dari 4 tahap yaitu: 


\section{Tahap Perencanaan Tindakan}

Pada tahap ini kegiatan-kegiatan yang dilaksanakan meliputi: (1) Menyiapkan rencana pelaksanaan Pembelajaran (RPP); (2) Menyiapkan lembar kerja siswa ( LKS ) dan soal-soal latihan; (3) Menyiapkan lembar Observasi guru; (4) Menyiapkan lembar Observasi siswa; (5) Menyiapkan lembar ajar yang akan disampaikan; dam (6) Menyusun tes hasil belajar dalam bentuk uraian untuk mengetahui prestasi belajar siswa.

\section{Tahap Pelaksanaan Tindakan}

Kegiatan yang dilakukan pada tahap ini adalah melaksanakan Rencana Pelaksanaan Pembelajan (RPP) yang telah direncanakan dikelas yaitu menerapkan pembelajaran kooperatif model CTL (Contextual Teaching and Learning) . Pada tahap pendahuluan, guru mensosialisasikan pada siswa mengenai pembelajaran kooperatif model CTL (Contextual Teaching and Learning ) yang akan digunakan dengan tujuan siswa cepat memahaminya, memberikan apersepsi dengan tanya jawab tentang kaitan pelajaran dengan kehidupan seharihari, misalnya dengan meminta siswa memperhatikan temannya langsung yang sedang berbelanja dikantin sekolah, memotivasi siswa dengan menyampaikan indikator hasil belajar, serta membagi siswa dalam beberapa kelompok sesuai dengan yang direncanakan.

Pada tahap berikutnya guru membagi LKS kepada masing-masing kelompok kemudian menjelaskan pokok-pokok materi pelajaran secara langsung. Setelah itu siswa berdiskusi dalam kelompoknya. Siswa diberi kesempatan untuk bertanya mengenai materi yang telah diberikan dan guru menanggapi pertanyaan siswa tersebut. Namun hanya beberapa siswa saja yang menyampaikan pertanyaan. Hal ini disebabkan karena siswa belum terbiasa dengan menggunakan pembelajaran kooperatif model CTL (Contextual Teaching and Learning). Guru bersama siswa membahas beberapa contoh soal yang ada pada buku LKS. Dalam membahas contoh soal,siswa diberikan kesempatan untuk mencoba menjawabnya dengan memperlihatkan jawabannya di papan tulis dan guru memberikan penjelasan cara yang sistematis dalam menjawab. Diantara siswa yang memperlihatkan jawabannya, sebagian besar siswa dapat menjawab dengan benar.

Tahap selanjutnya adalah pembimbingan siswa dalam melakukan latihan. Setiap kelompok yang telah dibentuk mengerjakan soal-soal latihan pada LKS yang telah dibagikan. Pada saat siswa melakukan latihan, guru memberikan bimbingan baik secara berkelompok maupun perorangan/individu. Pada saat diberikan bimbingan, banyak siswa yang menyampaikan ide/pendapatnya maupun pertanyaan kepada guru. Setelah melakukan diskusi kelompok, guru menunjuk beberapa siswa mempersentasikan hasil diskusi kelompoknya. Masing-masing kelompok mempersentasikan hasil diskusi kelompoknya, masing-masing kelompok-mempersentasikan jawaban soal latihan yang berbeda. Pada saat presentasi siswa dari kelompok lain hanya beberapa orang yangmemberikan tanggapannya. Pada tahap akhir yaitu pada tahap penutup, guru bersama siswa menarik kesimpulan dari hasil diskusi yang telah dilakukan. Kemudian siswa diberi PR dan meminta siswa untuk mempelajari materi pelajaran yang telah diberikan Pelaksanaan tindakan pada siklus 1 berlangsung dalam 3 pertemuan sesuai dengan rencana.

\section{Tahap Observasi dan Evaluasi}

\section{1) Observasi kegiatan Guru}

Proses pembelajaran siklus 1 pada setiap pertemuan di kelas,guru melaksanakan kegiatan mengajar sesuai RPP yang telah dibuat. Dari hasil observasi kegiatan guru siklus 1 dapat dilihat bahwa kegiatan yang telah dilakukan adalah memberikan apersepsi dan motivasi, pembahasan teori, membimbing siswa dalam pembelajaran, mendampingi siswa dalam 
diskusi kelompok, membimbing siswa dalam menyelesaikan tugas latihan, memberikan, memberikan umpan balik, dan mengakhiri pembelajaran. Berdasarkan lampiran 8, bahwa hasil yang diperoleh pada siklus 1 masih belum mencapai hasil yang diharapkan. Adapun kekurangan-kekurangan pada pelaksanaan pembelajaran adalah: (a) Guru kurang memotivasi siswa yaitu dengan tidak memberi kesempatan kepada siswa untuk bertanya dan menjawab pertanyaan guru berkaitan dengan pengetahuan pendahuluan. (b) Guru lebih banyak menunjuk siswa yang aktif dalam berdiskusi untuk mempersentasikan hasil diskusinya.

2) Obsevasi Aktivitas belajar siswa

Dari hasil análisis hasil observasi aktivitas belajar siswa untuk setiap siswa pertemuan pada siklus 1 diperoleh data sebagai berikut.

Tabel 2. Hasil Análisis Observasi Aktivitas Belajar Siswa Siklus 1

\begin{tabular}{|c|c|c|c|c|c|c|}
\hline \multirow{2}{*}{ Indikator } & \multicolumn{2}{|c|}{ Pertemuan 1} & \multicolumn{2}{|c|}{ Pertemuan 2} & \multicolumn{2}{|c|}{ Pertemuan 3} \\
\hline & Skor & $\%$ & Skor & $\%$ & Skor & $\%$ \\
\hline $\begin{array}{l}\text { Kesiapan siswa dalam menerima } \\
\text { materi pelajaran }\end{array}$ & 85 & $97,70 \%$ & 85 & $97,70 \%$ & 86 & $98,85 \%$ \\
\hline $\begin{array}{l}\text { Antusiasme siswa dalam mengikuti } \\
\text { pembelajaran }\end{array}$ & 60 & $68,97 \%$ & 68 & $78,16 \%$ & 69 & $79,31 \%$ \\
\hline $\begin{array}{l}\text { Aktivitas siswa dalam mengikuti } \\
\text { pembelajaran saat pembahasan contoh } \\
\text { soal dalam kelompok kecil }\end{array}$ & 60 & $68,97 \%$ & 77 & $88,51 \%$ & 77 & $88,51 \%$ \\
\hline $\begin{array}{l}\text { Aktivitas siswa dalam mengerjakan } \\
\text { latihan soal }\end{array}$ & 83 & $95,40 \%$ & 64 & $73,56 \%$ & 64 & $73,56 \%$ \\
\hline $\begin{array}{l}\text { Partisipasi siswa dalam mengakhiri } \\
\text { pembelajaran }\end{array}$ & 58 & $66,67 \%$ & 61 & $70,11 \%$ & 65 & $74,71 \%$ \\
\hline Jumlah & 346 & & 355 & & 361 & \\
\hline Rata-Rata & 11,93 & $79,54 \%$ & 12,24 & $81,61 \%$ & 12,45 & $82,99 \%$ \\
\hline Rata-Rata Siklus 1 & & & & 21 & & \\
\hline
\end{tabular}

Berdasarkan tabel diatas dapat ditentukan bahwa skor rata-rata aktivitas belajar siswa pada siklus 1 adalah 12,21. Berdasarkan kreteria yang telah ditentukan, hal ini berarti aktivitas belajar siswa tergolong dalam kategori sangat aktif. Hal ini menunjukkan bahwa indikator kerja untuk aktivitas belajar siswa telah tercapai. Adapun kekurangan-kekurangan siswa pada siklus 1 adalah sebagai:

a) Kerjasama siswa dalam diskusi kelompok belum maksimal dan siswa yang banyak berperan aktif adalah siswa yang pintar.

b) Keberanian siswa dalam mengajukan pertanyaan, merespon dan menjawab pertanyaan dari guru masih kurang.

c) Hanya beberapa siswa yang menanggapi hasil presentasi temannya

d) Siswa mengalami kesulitan dalam menyelesaikan soal-soal evaluasi siklus 1 .

3) Evaluasi

Setelah pembelajaran pada siklus 1 selesai, guru melakukan evaluasi. Evaluasi dilakukan dengan memberikan tes dalam bentuk uraian sebanyak 5 soal. Data hasil evaluasi siklus 1 dapat dilihat pada tabel 4 berikut.

Tabel 3. Hasil Evaluasi Siklus I

\begin{tabular}{|l|c|c|c|c|c|}
\hline \multirow{2}{*}{} & \multicolumn{5}{|c|}{ Nomor Soal } \\
\cline { 2 - 6 } & 1 & 2 & 3 & 4 & 5 \\
\hline Jumlah & 571 & 495 & 385 & 520 & 245 \\
\hline Rata-Rata & 18,42 & 15,97 & 12,42 & 16,77 & 7,90 \\
\hline
\end{tabular}




\begin{tabular}{|l|c|}
\hline Total & 2216 \\
\hline Rata-Rata Kelas & 71,48 \\
\hline Nilai Terendah & 49 \\
\hline Nilai Tertinggi & 100 \\
\hline Banyak Siswa Yang Mengikuti Tes & 31 \\
\hline Banyak Siswa Yang Tuntas & 25 \\
\hline Prosentase Ketuntasan & $81 \%$ \\
\hline
\end{tabular}

Berdasarkan tabel diatas, dapat diketahui bahwa jumlah siswa yang mengikuti evaluasi sebanyak 31 orang. Nilai rata-rata prestasi belajar siswa adalah 71,48. Hasil evaluasi siklus 1 menunjukkan bahwa setelah dianalisis, prosentase siswa yang telah tuntas belajar adalah $81 \%$. Hasil penelitian ini menunjukkan bahwa terdapat 6 siswa yang kurang mampu menyerap materi (tidak tuntas ). Hal ini menunjukkan bahwa indikator kerja untuk prestasi belajar siswa belum tercapai sehingga dilanjutkan ke siklus II.

\section{Tahap Refleksi}

Dari hasil yang diperoleh pada siklus 1, masih terdapat beberapa kekurangankekurangan. Kekurangan-kekurangan tersebut akan di perbaiki pada siklus II diantaranya adalah: (1) Guru lebih memperhatikan skenario pembelajaran khususnya dalam menyampaikan tujuan pembelajaran diawal pembelajaran. (2) Guru memberikan bimbingan kepada siswa dalam melakukan latihan dengan mengintensifkannya pada kelompok yang kurang/tidak aktif dalam berdiskusi. (3) Guru menghimbau kepada siswa untuk aktif dalam berdiskusi dan saling membantu sesama anggota kelompok. Siswa yang tidak aktif akan ditunjuk untuk mempresentasikan hasil diskusi kelompoknya. (4) Mengaktifkan tanya jawab dengan siswa dan memancing siswa untuk berpendapat pada saat pelaksanaan diskusi. (5) Memberikan kesempatan setiap kelompok untuk memberikan tanggapan pada hasil presentasi temannya. (6) Menyampaikan kembali beberapa konsep penting yang belum dikuasai oleh siswa yaitu tentang untung dan rugi.

\section{Deskripsi Siklus II}

Proses belajar mengajar siklus II berlangsung dalam 3 pertemuan. Pertemuan 1 berlangsung 3 x 40 menit dan pertemuan 2 berlangsung 2 x 40 menit. Sedangkan pertemuan 3 berlangsung selama $3 \times 40$ menit digunakan untuk diskusi lanjutan dan evaluasi selama 60 menit. Adapun sub pokok bahasan bruto, netto dan tara, dan memahami contoh soal tentang bruto, netto dan tara yang berkaitan dalam kehidupan sehari-hari diberikan pada pertemuan 1 dan pertemuan 2. Sedangkan pada pertemuan 3 dilakukan diskusi lanjutan dan kegiatan evaluasi. Kegiatan pada siklus II terdiri dari 4 tahap yaitu :

\section{Tahap Perencanaan Tindakan}

Pada tahap ini kegiatan-kegiatan yang dilakukan meliputi : (1) Menyiapkan rencana pelaksanaan Pembelajaran (RPP), (2) Menyiapkan lembar kerja siswa (LKS) dan soal-soal latihan, (3) Menyiapkan lembar Observasi guru, (4) Menyiapkan lembar Observasi siswa, (5) Menyiapkan lembar ajar yang akan disampaikan. (6) Menyusun tes hasil belajar dalam bentuk uraian untuk mengetahui prestasi belajar siswa.

\section{Tahap Pelaksanaan Tindakan}

Kegiatan pembelajaran pada siklus II dilaksanakan dengan melaksanakan Rencana Pelaksanaan Pembelajaran (RPP) yang telah dibuat dengan menerapkan pembelajaran kooperatif model CTL (Contextual Teaching and Learning). Pembelajaran siklus II ini dilaksanakan dengan memperbaiki kekurangan-kekurangan pada siklus I. Sehingga 
pelaksanaan pembelajaranpada siklus II ini hampir sama dengan pada siklus I. Pelaksanaan pembelajaran siklus II berlangsung dalam 3 pertemuan. Siswa mulai terbiasa dengan pembelajaran kooperatif model CTL (Contextual Teaching and Learning). Hal ini dapat dilihat dari keaktifan siswa dalam memberikan respon baik dalam bertanya maupun menjawab pertanyaan yang mengalami peningkatan. Dan juga terjadi peningkatan aktivitas siswa dalam melakukan diskusi kelompok dalam mengerjakan latihan pada LKS. Selain itu, banyak siswa dari kelompok lain yang memberikan tanggapannya pada saat persentasi hasil diskusi oleh kelompok lain yang memberikan tanggapannya pada saat presentasi hasil diskusi oleh kelompok yang lainnya. Siswa yang belum bisa menyelesaikan soal-soal, termotivasi untuk bertanya kepada anggota kelompok lainnya saat diskusi kelompok.

\section{Tahap Observasi dan Evaluasi}

Kegiatan guru pada siklus II yang terlaksana dengan baik sekali yaitu dalam memberikan apersepsi dan motivasi, pembahasan materi, membimbing siswa dalam pembelajaran, mendampingi siswa dalam diskusi kelompok, membimbing siswa dalam penyelesaian soal latihan, memberikan unpan balik, dan mengakhiri pembelajaran. Dari hasil análisis hasil observasi aktivitas belajar siswa untuk setiap pertemuan pada siklus II diperoleh data sebagai berikut.

Tabel 4. Hasil Análisis Observasi Aktivitas Belajar Siswa Siklus II

\begin{tabular}{|c|c|c|c|c|c|c|}
\hline \multirow{2}{*}{ Indikator } & \multicolumn{2}{|c|}{ Pertemuan 1} & \multicolumn{2}{|c|}{ Pertemuan 2} & \multicolumn{2}{|c|}{ Pertemuan 3} \\
\hline & Skor & $\%$ & Skor & $\%$ & Skor & $\%$ \\
\hline $\begin{array}{l}\text { Kesiapan siswa dalam menerima } \\
\text { materi pelajaran }\end{array}$ & 85 & $97,70 \%$ & 85 & $97,70 \%$ & 86 & $98,85 \%$ \\
\hline $\begin{array}{l}\text { Antusiasme siswa dalam mengikuti } \\
\text { pembelajaran }\end{array}$ & 60 & $68,97 \%$ & 68 & $78,16 \%$ & 69 & $79,31 \%$ \\
\hline $\begin{array}{l}\text { Aktivitas siswa dalam mengikuti } \\
\text { pembelajaran saat pembahasan contoh } \\
\text { soal dalam kelompok kecil }\end{array}$ & 60 & $68,97 \%$ & 77 & $88,51 \%$ & 77 & $88,51 \%$ \\
\hline $\begin{array}{l}\text { Aktivitas siswa dalam mengerjakan } \\
\text { latihan soal }\end{array}$ & 83 & $95,40 \%$ & 64 & $73,56 \%$ & 64 & $73,56 \%$ \\
\hline $\begin{array}{l}\text { Partisipasi siswa dalam mengakhiri } \\
\text { pembelaiaran }\end{array}$ & 58 & $66,67 \%$ & 61 & $70,11 \%$ & 65 & $74,71 \%$ \\
\hline Jumlah & 346 & & 355 & & 361 & \\
\hline Rata-Rata & 11,93 & $79,54 \%$ & 12,24 & $81,61 \%$ & 12,45 & $82,99 \%$ \\
\hline Rata-Rata Siklus 1 & & & & & & \\
\hline
\end{tabular}

Berdasarkan tabel ditas, dapat ditentukan bahwa skor rata-rata aktivitas belajar siswa pada siklus II adalah 13,11. Berdasarkan kretria yang telah ditentukan, hal ini berarti aktivitas belajar siswa tergolong dalam kategori sangat aktif. Hal ini menunjukan bahwa indikator kerja untuk aktivitas belajar siswa telah tercapai. Setelah pembelajaran pada siklus II selesai, guru melakukan evaluasi. Evaluasi dilakukan dengan memberikan tes dalam bentuk uraian sebanyak 5 soal. Data hasil evaluasi siklus II dapat dilihat pada tabel berikut.

Tabel 5. Hasil Evaluasi Siklus II

\begin{tabular}{|l|c|c|c|c|c|}
\hline \multirow{2}{*}{ Jumlah } & \multicolumn{5}{|c|}{ Nomor Soal } \\
\cline { 2 - 6 } & 1 & 2 & 3 & 4 & 5 \\
\hline Rata-Rata & 571 & 495 & 385 & 520 & 245 \\
\hline Total & 18,42 & 15,97 & 12,42 & 16,77 & 7,90 \\
\hline Rata-Rata Kelas & \multicolumn{5}{|c|}{2216} \\
\hline
\end{tabular}




\begin{tabular}{|l|c|}
\hline Nilai Terendah & 49 \\
\hline Nilai Tertinggi & 100 \\
\hline Banyak Siswa Yang Mengikuti Tes & 31 \\
\hline Banyak Siswa Yang Tuntas & 25 \\
\hline Prosentase Ketuntasan & $81 \%$ \\
\hline
\end{tabular}

Berdasarkan tabel diatas, dapat diketahui bahwa jumlah siswa yang mengikuti evaluasi sebanyak 31 orang, nilai rata-rata prestasi belajar siswa adalah 78,87 . Hasil evaluasi siklus II menunjukkan bahwa setelah dianálisis, persentase siswa yang telah tuntas belajar adalah $87 \%$. Hasil penelitian ini juga menunjukkan bahwa terdapat 4 siswa yang kurang mampu menyerap materi (tidak tuntas). Dapat disimpulkan bahwa indikator kerja untuk prestasi belajar siswa telah tercapai.

\section{Tahap Refleksi}

Karena indikator kerja telah tercapai kerja tercapai baik untuk aktivitas maupun prestasi belajar siswa maka dapat dikatakan penelitian telah berhasil. Dari hasil evaluasi siklus I dan II, nilai rata-rata hasil belajar siswa yang diperoleh dari siklus ke siklus mengalami peningkatan. Peningkatan hasil belajar siswa juga didukung oleh adanya peningkatan aktivitas belajar siswa. Dengan menerapkan model pembelajaran kooperatif CTL (Contextual Teaching and Learning) telah dapat meningkatkan aktivitas dan hasil belajar siswa kelas VII.2 SMP Negeri 1 Pemenang. Hasil penelitian ini didukung oleh hasil penelitian Burungge (2020) dan Asmawati (2018) yang menjelaskan bahwa model pembelajaran kooperatif CTL (Contextual Teaching and Learning) dapat meningkatkan hasil belajar siswa, disamping itu suasana kelas menjadi lebih hidup dengan partisipasi siswa yang aktif dengan kegiatankegiatan pembelajaran yang dilakukannya. Yang akhirnya membuat siswa lebih bersemangat mengikuti pelajaran, sehingga pembelajaran menjadi semakin lebih baik.

\section{Kesimpulan}

Kesimpulan yang dapat diambil dalam penelitian ini adalah hasil belajar siswa mengalami peningkatan rata-rata $9 \%$ diperoleh dari rata-rata evaluasi hasil belajar siswa dari siklus I adalah 76\% kemudian meningkat pada siklus II menjadi $85 \%$. Berdasarkan analisis data selama siklus I dan II dapat disimpulkan: (1) Penerapan model pembelajaran kooperatif CTL menjadi alternatif terbaik pada pembelajaran matematika, (2) Penerapan model kooperatif dapat menciptakan pembelajaran yang partisipatif dan multiarah, (3) Melalui penerapan model pembelajaran kooperatif CTL dapat meningkatkan hasil belajar siswa. Hasil penelitian juga menunjukkan perubahan suasana kelas yang cenderung demokratis dan perubahan sikap guru untuk lebih peduli terhadap suasana kelas.

\section{Saran}

Adapun saran yang dapat dikemukakan dari hasil penelitian ini adalah sebagai berikut: (1) Diharapkan kepada guru bidang studi matematika agar mempertimbangkan perkembangan dan taraf berpikir siswa sebagai acuan dalam memilih model pembelajaran. (2) Bagi pihakpihak yang ingin meneliti lebih lanjut tentang pembelajaran kooperatif model CTL (Contextual Teaching and Learning) agar dapat mengimplementasikannya pada materi yang lain dengan kreasi media yang inovatif.

\section{Daftar Pustaka}

Asmawati, A. (2018). Penerapan Metode Contextual Teaching And Learning Tipe Modeling untuk Meningkatkan Hasil Belajar Siswa pada Mata Pelajaran Agama Islam dan 
Budi Pekerti di SMAN 3 Mataram. Jurnal Kependidikan: Jurnal Hasil Penelitian dan Kajian Kepustakaan di Bidang Pendidikan, Pengajaran dan Pembelajaran, 4(1), 1-8. doi:https://doi.org/10.33394/jk.v4i1.895

Burengge, S. (2020). Penerapan Model Pembelajaran Kooperatif Tipe STAD dengan Pendekatan Kontekstual bagi Siswa SDN 7 Tentena Sulawesi Tengah. Jurnal Paedagogy, 7(4), 275-280. doi:https://doi.org/10.33394/jp.v7i4.2832

Heryekti Pujingsih, R. (2021). Meningkatkan Motivasi dan Hasil Belajar Matematika dengan Metode Kooperatif Tipe Jigsaw di SMA Negeri 1 Gerung. Jurnal Paedagogy, 8(1), 50-56. doi:https://doi.org/10.33394/jp.v8i1.3196

Munif Khatib. (2013). Gurunya Manusia Menjadikan Semua Anak Istimewa dan Semua Anak Juara. Bandung: Kaifa Mizan Pustaka.

Muhammad Asrori. (2007). Penelitian Tindakan Kelas. Bandung: Wacana Prima

Nilawati, N. (2021). Upaya Meningkatkan Aktivitas Belajar Siswa dalam Pembelajaran IPA Melalui Model Pembelajaran Kooperatif Tipe Jigsaw di SMP Negeri 7 Bukittinggi Provinsi Sumatra Barat. Jurnal Paedagogy, 8(3), 398-407. doi:https://doi.org/10.33394/jp.v8i3.3850

Roestiyah, N.K. (2001). Strategi Belajar Mengajar. Jakarta: Rineka Cipta.

Saufi, I., \& Rizka, M. (2021). Analisis Pengaruh Media Pembelajaran Film Dokumenter Terhadap Motivasi Belajar Siswa. Jurnal Teknologi Pendidikan : Jurnal Penelitian dan Pengembangan Pembelajaran, 6(1), 55-59. doi:https://doi.org/10.33394/jtp.v6i1.3626

Suarni, G., Rizka, M., \& Zinnurain, Z. (2021). Analisis Pengaruh Penerapan Model Pembelajaran Sains Teknologi Masyarakat Terhadap Hasil Belajar Siswa. Jurnal Paedagogy, 8(1), 31-38. doi:https://doi.org/10.33394/jp.v8i1.3226

Suryani, E. (2018). Meningkatkan Hasil Belajar Ekonomi Melalui Pembelajaran Kooperatif Metode Think Pair Share pada Siswa Kelas XI SMA Negeri 3 Mataram. Jurnal Kependidikan: Jurnal Hasil Penelitian dan Kajian Kepustakaan di Bidang Pendidikan, Pengajaran dan Pembelajaran, 4(2), 141-150. doi:https://doi.org/10.33394/jk.v4i2.1122

Zaini, Hisyam. Dkk. (2008). Strategi Pembelajaran Aktif. Yogyakarta: Pustaka Insan Madani. 